\title{
Aspects of reproductive biology of the lesser spiny eel Macrognathus aculeatus (Bloch, 1786) from river Ganga, Uttar Pradesh, India
}

\author{
AYSHA AZIZ FARIDI, FARAH BANO* AND M. SERAJUDDIN** \\ Department of Biosciences, Jamia Millia Islamia, New Delhi - 110 025, India \\ *Department of Zoology, University of Lucknow, Lucknow - 226 007, Uttar Pradesh, India \\ e-mail:lu.fisheries@gmail.com
}

\begin{abstract}
A total of 315 samples of Macrognathus aculeatus (Bloch, 1786) were collected for this study from the river Ganga at Sant Ravidas Nagar, Bhadohi, Uttar Pradesh during June 2016 to May 2017. Chi-square test $\left(\chi^{2}\right)$ confirmed that the male to female sex ratio was 1:0.93 which was not significantly different from hypothetical ratio of 1:1. The maximum numbers of stage IV gonads were encountered during the month of June indicated its spawning period. Mass and length ratio showed a negative allometric growth $(b<3)$ in males (2.08102), females $(2.50212)$ and for the sexes pooled $(2.25371)$. The maximum and minimum values of condition factor for both the sexes of $M$. aculeatus were recorded during non-breeding and breeding seasons respectively. The ova diameter of ripe eggs of M. aculeatus ranged between 1.25-1.40 mm during the month of June while the single mean peak value (male $=1.40 \pm 0.091$; female $=4.49 \pm 0.059)$ of the gonado-somatic index pointed out that the fish has only one breeding season during monsoon. Absolute fecundity varied from 800 to 1510 , with an average value of 1247 eggs. Fecundity was found to be highly correlated with the total length $(r=0.9041)$, body weight $(r=0.8901)$, ovary length $(\mathrm{r}=0.8721)$ and ovary weight ( $\mathrm{r} 0.9210)$ which were found to be significant $(\mathrm{p}<0.001)$.
\end{abstract}

Keywords: Fecundity, Ganga River, Macrognathus aculeatus, Reproduction

\section{Introduction}

Studies on reproductive biology of fish is considered to be important for their management under controlled conditions and also from the evolutionary point of view (Kashyap et al., 2016). The knowledge of reproductive potential of fish can be used in formulating the degree of rearing facilities needed and to assess the aquacultural potential. Reproductive biology studies in fish include the assessment of sex ratio, maturity stages, duration of reproductive season, gonadosomatic index (GSI) and quantification of reproductive capacity (Maurua et al., 2003; De Carvalho et al., 2009; Fontoura et al., 2009; Cardoso et al., 2019). Reproductive biology is one of the most important biological aspects which is a prerequisite for evaluation of the commercial potentialities of a fish stock and its preservation, conservation and management prospects (Jakobsen et al., 2009; Hliwa et al., 2017; Cardoso et al., 2019). GSI has been used as an indicator of reproductive activity of fish and for determination of the breeding season (Sley et al., 2015; Almukhtar et al., 2016). The condition factor is affected by food availability, environmental conditions, population density, physical factors and the physiology of fish including development of gonad maturity (Parrish and Mallicoate, 1995; Uthayakumar et al., 2013).
The spiny eel, M. aculeatus is one of the common species of Mastacembeliformes and widely distributed in different freshwater habitats of Asian and Southeast Asian countries such as Bangladesh, China, India, Indonesia, Korea, Laos, Malaysia, Nepal, Singapore, Taiwan, Thailand and Vietnam (Jayaram, 1981; Das and Kalita, 2003; Rahman et al., 2012). The spiny eels inhabit mainly in medium to large sized rivers and are abundantly distributed in low lying wetlands, freshwater streams, ponds, canals, beels and tanks. They are also available in freshwater and brackishwater within tidal influence and are benthopelagic and potamodromous in nature (Bhuiyan, 1964; Taki, 1978; Riede, 2004). They are often found in small puddles in which mud abounds and popularly known as the 'ditch eels' (Hora, 1935) and are also known as the 'lesser spiny eels' (Munro, 1955). M. aculeatus attain upto 15 inches in length and are considered as commercially important species, palatable as an excellent food fish with high nutritive value (Day, 1878; Sahoo et al., 2009) and also used as an aquarium species (Vidthayanon, 2002). Hossain et al. (1999) pointed out the high nutritional value of $M$. aculeatus as it contains $15.3 \%$ carcass protein, $22.1 \%$ muscle protein, $4.12 \%$ lipid, $78.1 \%$ moisture, $2.3 \%$ ash and $5.3 \mathrm{KJ} \mathrm{g}^{-1}$ energy. Prasad et al. (1983) also reported the seasonal variation in fat and water content of this fish and the serum cholesterol level was minimal (155.0 \pm 29.5 $\mathrm{mg} \mathrm{ml}^{-1}$ ) as recorded by Chandra (1982). 
M. aculeatus occupies the third level in the food chain in waters and also helps to control water pollution by consuming detritus (Rahman et al., 2009). The demand of the species always exceeds the supply and the supply mostly depends on the capture resources (Sahoo et al., 2009). M. aculeatus is under the category of 'least concern' according to the International Union of Conservation of Nature (IUCN, 2018). In spite of its preference and palatability, very less information is available on the biology of this fish species (Rahman et al., 2012). A survey of literature showed that very little work has been carried out on different aspects of the biology of $M$. aculeatus inspite of its economic importance. The studies include the estimation of fecundity of M. aculeatus in India (Prasad et al., 1979); length-weight and lengthlength relationship (Lazarus and Reddy, 1986; Hossain et al., 2006), reproductive biology (Nabi and Hossain, 1996), sex ratio, length-frequency distributions and morphometric relationships of length-length and lengthweight (Rahman et al., 2012). Qasim and Qayyum (1961) studied the spawning frequencies and breeding season of Rhynchobdella aculeata (M. aculeatus).

Keeping in mind the paucity of information on the biology of this species, the present study was planned to determine the length-weight relationship, condition factor, sex ratio, gonadosomatic index (GSI) and fecundity of M. aculeatus.

\section{Materials and methods}

Collection of fish samples

A total of 315 specimens of the spiny eel, M. aculeatus were collected from the Ganga River passing from Sant Ravidas Nagar, Bhadohi $\left(25^{\circ} 9^{\prime} \mathrm{N}-25^{\circ} 32^{\prime} \mathrm{N}\right.$; $82^{\circ} 14^{\prime} \mathrm{E}-82^{\circ} 45^{\prime} \mathrm{E}$ ) using cast nets and gillnets (mesh size $=3$ to $4.5 \mathrm{~cm}$ ) during June 2016 to May 2017. The individuals were primarily cleaned with distilled water and two body parameters viz., total length (TL) and body weight (BW) were measured.

\section{Weight-length ratio and condition factor}

Weight and length relation was established using the equation $\mathrm{BW}=\mathrm{a}{ }_{*} \mathrm{TL}^{\mathrm{b}}$ (Le Cren 1951), where, $\mathrm{BW}$ is the total weight and TL is the total length. Parameter ' $\mathrm{a}$ ' and ' $b$ ' were calculated by means of a linear regression on transformed data $(\log \mathrm{BW}=\log \mathrm{a}+\mathrm{b} \log \mathrm{TL})$, where ' $\mathrm{a}$ ' is the intercept and ' $b$ ' represents the slope of the regression line. Covariance analysis (ANCOVA) was performed to determine possible differences between the parameters for males and females.

Monthly variations in the body condition of fish were obtained using Fluton's condition factor $(\mathrm{K})$, using the formula: $\mathrm{K}=\mathrm{BW} \times 100 / \mathrm{TL}^{3}$ which indicates the type of growth (King, 2013).

\section{Reproductive biology}

To determine the sex, an abdominal incision was made and the gonads were removed and cleaned with distilled water. Weight and length of ovary were taken and then preserved in $4 \%$ formaldehyde solution in labelled vials for further studies. Stages of maturity were determined according to the method suggested by Qayyum and Qasim (1964) for the tropical and subtropical fishes. Identification of gonadal conditions was done on the basis of their colour, appearance and their extent in the body cavity.

\section{Gonadsomatic index (GSI)}

GSI for each fish was computed by expressing the gonad weight as percentage of the total body weight. GSI was calculated using the standard formula:

$$
\mathrm{GSI}=(\mathrm{OW} / \mathrm{BW})_{*} 100
$$

where, $\mathrm{OW}=$ weight of gonad in $\mathrm{g}, \mathrm{BW}=$ weight of the fish in $\mathrm{g}$.

\section{Ovarian diameter}

Intraovarian eggs were measured and their diameters were taken with the help of an ocular micrometer using $8 \times 12.5$ magnification of binocular dissecting microscope.

\section{Fecundity}

Fecundity evaluation was carried out by taking $10 \mathrm{mg}$ subsamples of eggs from the anterior, middle and posterior regions of each ovary. Ova present in the subsamples were counted using binocular dissecting microscope at 1 x 12.5 magnification and their average count was multiplied by the total weight of the ovary for the determination of absolute fecundity.

Fecundity (F) $=\mathrm{N} \times$ Weight of gonad (OW)

where, $\mathrm{N}=$ No. of eggs in sample

Relationships of fecundity with various parameters (TL, BW, OL and OW) were also worked out. The probability level was set as less than 0.05 .

\section{Results}

Sex ratio

The male:female sex ratio $(\delta: P)$ recorded in the present study was 1:0.93. However, the chi-square test $\left(\chi^{2}\right)$ showed no significant departure from the hypothetical ratio (1:1). Male M. aculeatus maintained numerical superiority over female (Table 1) in all months except during February, August, September and December. The sex ratio also varied with size which was found to be non-significant $(\mathrm{p}>0.05)$ from the hypothetical ratio (1:1) in all size groups (Table 2). 
Table 1. Sex ratio of M. aculeatus in different months sampled from river Ganga

\begin{tabular}{lllllll}
\hline Months & Male abundance & Female abundance & Sexes combined & Sex ratio $\left(\delta^{\uparrow}:+\right.$ ) & Chi-square value $\left(\chi^{2}\right)$ & Significance \\
\hline Jan & 24 & 20 & 44 & $1: 0.83$ & 0.366 & NS \\
Feb & 13 & 14 & 27 & $1: 1.07$ & 0.036 & NS \\
Mar & 14 & 10 & 24 & $1: 0.71$ & 0.685 & NS \\
Apr & 16 & 14 & 30 & $1: 0.87$ & 0.133 & NS \\
May & 6 & 6 & 12 & $1: 1$ & 0.0 & NS \\
Jun & 17 & 13 & 30 & $1: 0.76$ & 0.542 & NS \\
Jul & 12 & 8 & 20 & $1: 0.66$ & 0.833 & NS \\
Aug & 20 & 22 & 42 & $1: 1.09$ & 0.095 & NS \\
Sep & 8 & 12 & 20 & $1: 1.5$ & 0.183 & NS \\
Oct & 11 & 5 & 16 & $1: 0.43$ & 2.618 & NS \\
Nov & 11 & 7 & 18 & $1: 0.63$ & 0.934 & NS \\
Dec & 12 & 20 & 32 & $1: 1.66$ & 2.13 & NS \\
Total & 164 & 151 & 315 & & & \\
Mean & 13.66 & 12.58 & & $1: 0.93$ & & NS \\
\hline
\end{tabular}

$\delta=$ Males,,$+=$ Females, NS $=$ Non-significant

Table 2. Sex ratio of M. aculeatus in different size groups sampled from river Ganga

\begin{tabular}{lllllll}
\hline Size range $(\mathrm{mm})$ & Male abundance & Female abundance & Sexes combined & Sex ratio $\left(\delta^{\Uparrow}:\right.$ P $)$ & Chi-square value $\left(\chi^{2}\right)$ & Significance \\
\hline $7-10$ & 18 & 12 & 30 & $1: 0.66$ & 1.25 & NS \\
$11-14$ & 27 & 11 & 38 & $1: 0.40$ & 4.18 & NS \\
$15-18$ & 19 & 22 & 41 & $1: 1.15$ & 0.22 & NS \\
$19-22$ & 22 & 18 & 40 & $1: 1.22$ & 0.40 & NS \\
$23-26$ & 23 & 24 & 47 & $1: 1.04$ & 0.02 & NS \\
$27-30$ & 24 & 26 & 50 & $1: 1.08$ & 0.27 & NS \\
$31-34$ & 22 & 28 & 50 & $1: 1.27$ & 0.73 & NS \\
$35-38$ & 09 & 10 & 19 & $1: 1.24$ & 0.05 & NS \\
\hline Total & 164 & 151 & & & & NS
\end{tabular}

$\widehat{\delta}=$ Males, $\$=$ Females, $\mathrm{NS}=$ Non-significant

\section{Gonads and maturity stages}

Testes of M. aculeatus are paired, slender and creamy white in colour, located dorsally in the abdominal cavity which elongate with ripening and extend towards the posterior half of the abdomen. The testes are suspended by a delicate and thin mesentary called mesorchia. From the anterior inner margin of each testis arises a vas efferens which runs along the whole length of the testis. The two vas efferens of the two sides join posteriorly to form a common duct, the vas defferens that communicates with the exterior.

Ovaries of $M$. aculeatus are paired and elongated, situated in the posterior half of the body cavity and are suspended medially by mesovaria. Ripe ovaries are light yellow in colour. Anteriorly, the two lobes representing the two ovaries are free, but posteriorly they bend downwards and inwards to form a short single oviduct, which leads to the genital aperture.

In the present study, five maturity stages were recognised in both males and females of $M$. aculeatus
(Table 3; Fig. 1). In both sexes, gonads show a regular seasonal development with little overlap in different phases of maturation. Spawning season of M. aculeatus was estimated on the basis of the occurrence of adults in different stages of maturity in each month. Both sexes were completely matured in the month of June with ripe gonads (stage IV).

\section{GSI}

Remarkable changes were observed in the weight of gonads during development. Low GSI indicated the inactive phase of gonads (January-February and OctoberDecember). As gonadal activity picked up, the GSI also increased, attaining the peak value in the ripe stage. GSI increased markedly from May and peaked in the month of June in both the sexes and declined rapidly at the onset of spawning in August as it was indicated by the appearance of spent specimens (Fig. 2). Therefore, it was concluded that the fish spawned once in a year with one spawning peak. In the present study, comparatively high values of GSI in both male $(1.40 \pm 0.091)$ and female $(4.49 \pm 0.059)$ were recorded in the breeding season during May to June. 
Table 3. Maturity stages of gonads in M. aculeatus

\begin{tabular}{lll}
\hline Stage & Testes & Ovary \\
\hline $\begin{array}{l}\text { Stage I } \\
\text { (Immature virgin) }\end{array}$ & $\begin{array}{l}\text { Testes are small, paired, slender, thread like, } \\
\text { distinguished microscopically from the ovaries. } \\
\text { Vasa deferentia not very distinct and difficult } \\
\text { to locate }\end{array}$ & $\begin{array}{l}\text { Structures extending one third of the body } \\
\text { cavity. Eggs of circular shape, semitransparent }\end{array}$ \\
\hline $\begin{array}{l}\text { Stage II (Maturing virgin } \\
\text { or Recovering spent) }\end{array}$ & $\begin{array}{l}\text { Testes slightly elongated, opaque and white in } \\
\text { colour. Vasa diferentia distinct and easy to locate }\end{array}$ & $\begin{array}{l}\text { Ovaries thin, slightly elongated. Ova spherical } \\
\text { opaque }\end{array}$ \\
\hline Stage III (Ripening) & $\begin{array}{l}\text { Testes ivory in colour, more prominent than Stage } \\
\text { II. Viscous fluid oozes out with slight pressure on } \\
\text { the abdomen }\end{array}$ & $\begin{array}{l}\text { Ovaries yellowish, elongated, slightly lobulated, } \\
\text { the entire length of the body cavity. Eggs visible } \\
\text { to naked eye }\end{array}$ \\
\hline $\begin{array}{l}\text { Stage IV (Ripe or Fully } \\
\text { mature) }\end{array}$ & $\begin{array}{l}\text { Testes flabby, massive, creamy white in colour, } \\
\text { grown to maximum in size, occupying substantial } \\
\text { part of the body cavity and discharge white milt } \\
\text { on gentle pressure. }\end{array}$ & $\begin{array}{l}\text { Ovaries yellow white in colour, ovarian membrane } \\
\text { very thin. Eggs opaque and very distinct, almost } \\
\text { round and and easilected if slight pressure is applied } \\
\text { on the abdomen }\end{array}$ \\
\hline Stage V (Spent) & $\begin{array}{l}\text { Testes shrunken, their weight drastically reduced } \\
\text { in this stage. No milting with pressure on } \\
\text { abdomen }\end{array}$ & $\begin{array}{l}\text { Ovaries flabby, shrunken and left with only a few } \\
\text { residual ova in recently spawned fish. Majority } \\
\text { of ova small, transparent, invisible to naked eye. }\end{array}$ \\
\hline
\end{tabular}

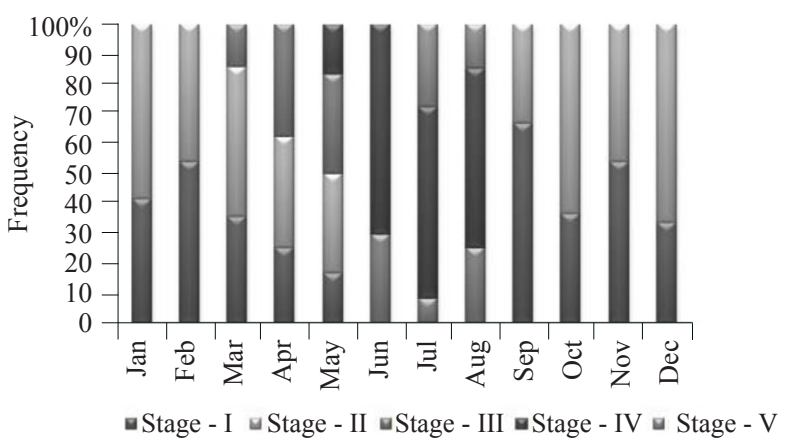

(a)

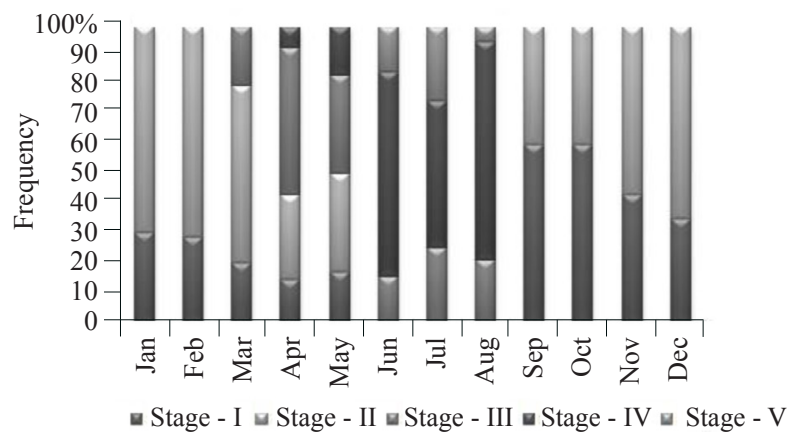

(c)

Fig. 1. Maturity stages of M. aculeatus in different months sampled from river Ganga. (a) Males and (b) Females

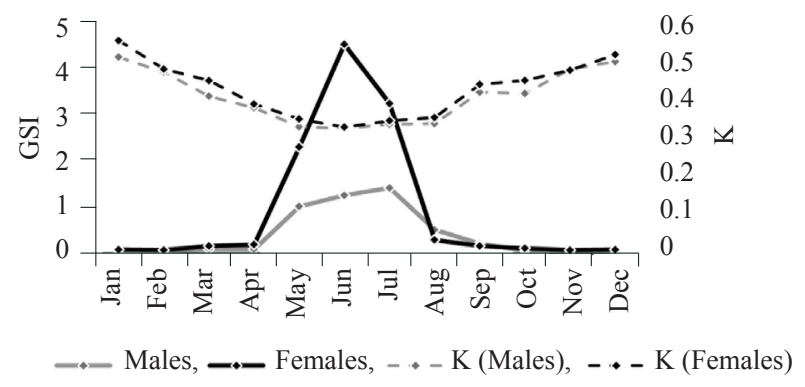

Fig. 2. Mean values of the gonadosomatic index (GSI) and condition factor $(\mathrm{K})$ in males and females of M. aculeatus

\section{Weight-length ratio and condition factor}

The weight-length ratio showed significant difference between genders (ANCOVA, $\mathrm{p}<0.05)$. The growth coefficient was lower than three $(b<3)$, indicating that M. aculeatus shows a negative allometric growth for males (2.08102), females (2.50212) and for combined sexes
(2.25371). The rate of change in weight relative to length obtained in size range of 7-38 cm yielded the following equations: Males: $\log \mathrm{BW}=-4.73810+2.08102 \mathrm{Log} \mathrm{TL}$; Females: $\log \mathrm{BW}=-6.10542+2.50212 \log$ TL; Sexes combined (Males and Females): $\log \mathrm{BW}=-5.31351+$ $2.25371 \mathrm{Log}$ TL. The average values of condition factor (K) of $M$. aculeatus ranged from 0.32151 to 0.5060 (males) and 0.3251 to 0.5487 (females) with maximum and minimum value during January (non-breeding time) and June (peak breeding time) respectively. The details are given in Fig. 2.

\section{Ova diameter}

In the present study, the size of ova ranged between $0.35-1.70 \mathrm{~mm}$ while the ripe eggs of $M$. aculeatus were spherical and diameter ranged between 1.25-1.40 mm during the month of June (Fig. 3). The diameter of ova collected from anterior, middle and posterior regions of the ripe ovary were almost of the same size. Likewise, 


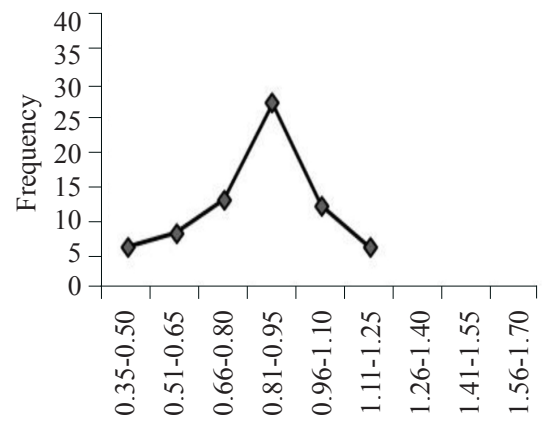

Size range $(\mathrm{mm})$

(a)

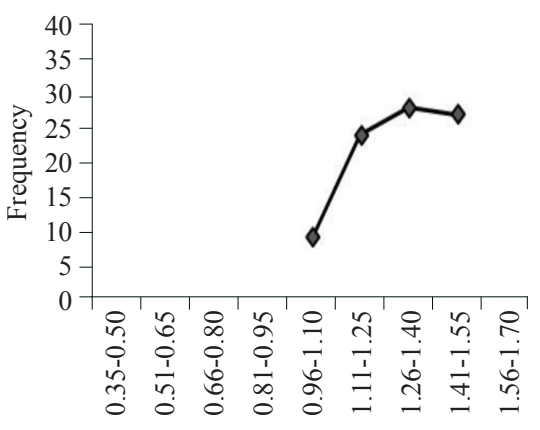

Size range $(\mathrm{mm})$

(d)

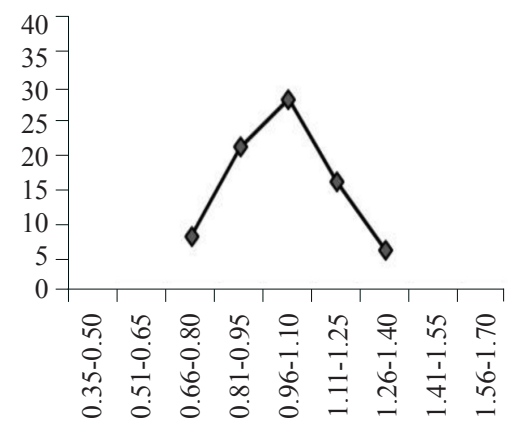

Size range $(\mathrm{mm})$

(b)

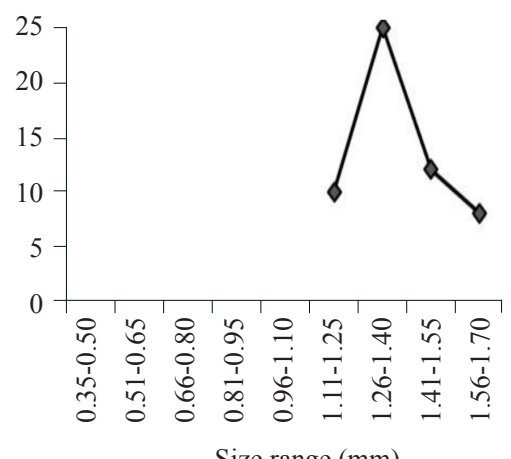

(e)

Fig. 3. Size frequency distribution of intraovarian oocytes of M. aculeatus sampled from river Ganga. (a) March, (b) April, (c) May, (d) June and (e) July

the ova from the two lobes of gonads were also of similar diameter.

\section{Fecundity}

In the present study, absolute fecundity varied from 800 to 1510 , with an average value of 1247 in the specimens of $M$. aculeatus. Fecundity was also found to be highly correlated with the TL and BW with values of correlation coefficient ' $r$ ' 0.9041 and 0.8901 respectively and significant at $p<0.001$. Also, the values of correlation coefficient were 0.8721 and 0.9210 for fecundity-OL and fecundity-OW relationships respectively (Table 4).

\section{Discussion}

In the present study, males outnumbered females of $M$. aculeatus. Male dominancy over female may be due to accidental or natural mortality such as spawning stress of females in the population. Similar results were

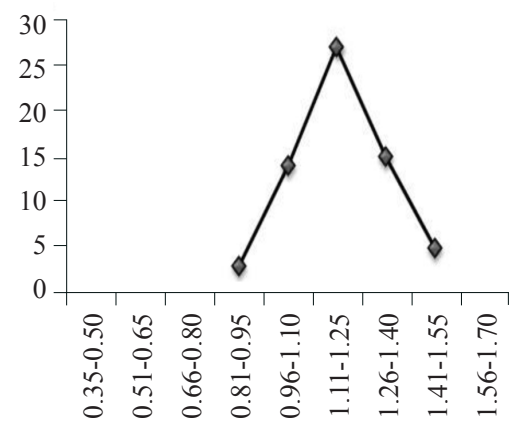

Size range $(\mathrm{mm})$

(c)

Table 4. Logarithmic regression equations of various relationships in M. aculeatus

\begin{tabular}{llll}
\hline Relationship & Regression Equations & Correlation coefficient $\left(\mathrm{r}^{2}\right)$ & $\mathrm{p}$ value \\
\hline Fecundity-TL & $\log \mathrm{F}=3.10+0.83 \log \mathrm{TL}$ & 0.9041 & 0.001 \\
Fecundity-BW & $\log \mathrm{F}=3.71+0.52 \log \mathrm{BW}$ & 0.8901 & 0.001 \\
Fecundity-OL & $\log \mathrm{F}=2.08+1.57 \log \mathrm{OL}$ & 0.8721 & 0.001 \\
Fecundity-OW & $\log \mathrm{F}=3.12+0.17 \log \mathrm{OW}$ & 0.9210 & 0.001 \\
\hline
\end{tabular}

reported by Abujam and Biswas (2011) and Kashyap et al. (2016). However, it is worth mentioning here that several other workers (Qayyum and Qasim, 1964; Cardoso et al. 2019) recorded the dominance of females over males. In the present study, male and female sex ratio was 1:0.93 which did not differ significantly from the hypothetical sex ratio of 1:1. Rahman et al. (2012) reported that male and female sex ratio in $M$. aculeatus was 1:1.35 which differed significantly from the expected value of $1: 1$. The minor differences in the sex ratio could be attributed to the differences in the growth between sexes, sexual dimorphism and mortality rates.

In M. aculeatus, the cycle of maturation and depletion of gonads occurs only once in a year and synchronised in both the sexes. It was observed during the present study that both male and female $M$. aculeatus had higher GSI values during May to June, which indicated that the fish 
has only one breeding season and spawns during this time with a peak value of $1.40 \pm 0.091$ for male and $4.49 \pm 0.0590$ for female. Similar observations were perceived by Nabi and Hossain (1996) in the spiny eel, M. aculeatus. Ali et al. (2003) reported that the GSI in M. aculeatus ranged from $0.44 \pm 0.06$ to $14.40 \pm 1.48$ while Sultana et al. (2017) reported the mean GSI of all samples of $M$. aculeatus as $12.50 \pm 1.38$.

In the present study, most of the stage IV ripe gonads were recorded from May to July and spawning was found to be at its peak in core monsoon period. An increase in GSI value means the advancement of maturity. High value of GSI in both males and females during the period from May to July indicated full development of gonads. Recovering gonads of stage II remain quiescent from October through January, because during this period both temperature and photoperiod remained minimum. During February/March an increase in development of gonads takes place with the increase in temperature. Peak condition of development of gonads was recorded during June when both temperature and photoperiod were maximum.

According to Le Cren's (1951) concept of 'cube law' the value of ' $b$ ' for an ideal fish must be 3.0, but this value may vary significantly from one species to another. In the present study, it was found that both adult males and females follow negative allometric growth pattern $(b<3)$ and the species during its development exhibited a more increase in length than in weight (Le Cren, 1951; Froese, 2006). The rate of increase in weight in relation to length (regression coefficient, b) was found to be higher in females than males, which could be attributed to the enormous growth of ovaries in females.

In the current study, maximum condition factor $(\mathrm{K})$ was observed in the month of January (non-breeding time) and minimum in June (peak breeding time) in both the sexes. The condition factor decreased with growth and corresponding increase in weight with maximum value during non-breeding seasons while it reduced at peak breeding season in the closely related spiny eel, Mastacembelus armatus (Uthayakumar, 2013). The high values of GSI and low condition factor were recorded in the month of June which indicated that there exists no relation between GSI and condition factor. The present finding is in corroboration with Cardoso et al. (2019) who reported the reverse pattern for mean condition factor and GSI in Prochilodus lacustris. The condition factor relatively depended upon a number of factors such as environmental conditions and ecological parameters, seasons, food availability, gonadal development, fishing pressures and stress conditions (Zargar et al., 2012; Ahmad, 2013; Ali et al., 2014, Komsari et al., 2015).
According to Qasim and Qayyum (1961), breeding has direct relation with monsoon cycle and freshwater teleosts found in the plains of Uttar Pradesh have their breeding season from July to September end. The breeding behaviour of $M$. aculeatus seems to follow the same pattern and have relatively short spawning seasons from late May and gradually progresses to the middle of June and late July when the rivers are flooded with rain water. Present finding is also in accordance with the findings of Narejo et al. (2003) and Rahman et al. (2006) who observed that $M$. armatus has only one breeding season during May to July with a peak in July as well as with that of Nabi and Hussain (1996) in spiny eel, M. aculeatus.

Fully developed and ripe eggs were spherical with diameter ranging between $1.25-1.40 \mathrm{~mm}$. Similar to the present findings, Nabi and Hussain (1996) also reported that the eggs were spherical and uniform in diameter (1.00 $\mathrm{mm}$ ) in ripe gonads of $M$. aculeatus.

In the current study, fecundity varied from 800 to 1510 , with an average value of 1247 in the specimens of M. aculeatus ranging between $12-19 \mathrm{~cm}$ in size. Prasad et al. (1979) estimated the fecundity (210-1828) of $M$. aculeatus in India. In the present study, highly significant $(p<0.001)$ correlation co-efficient $(r)$ was observed between fecundity-TL (0.9041), fecundityBW (0.8901), fecundity-OL (0.8721) and fecundity-OW (0.9210) for M. aculeatus. Taslim et al. (2002) pointed out that the co-efficient of correlation between fecundity versus $\mathrm{TL}$ and $\mathrm{BW}$ were found to range from $0.34-0.45$ and 0.33-0.59 respectively in $M$. aculeatus. Similar observations were reported by many authors such as Das et al. (1989) in Heteropneustes fossilis, Khan et al. (2002) in Plotosus canius, Rheman et al. (2002) in Liza parsia and by Kashyap et al. (2016) in Channa punctatus. The finding of this study could be useful for management of the $M$. aculeatus stocks in the wild populations as well as under captive culture conditions.

\section{Acknowledgements}

The authors thank the Head, Department of Zoology, University of Lucknow for providing facilities and administrative support. Author FB is thankful to the University Grants Commission (UGC), New Delhi the award of Senior Research Fellowship [Ref No19/06/2016(i) EU-V].

\section{References}

Abujam, S. S. and Biswas, S. P. 2011. Studies on the reproductive biology of spiny eel, Macrognathus aral from upper Assam. J. Environ. Biol., 32: 635-639.

Ahmad, F. M. Y. 2013. Length-weigh relationships, relative condition factor, and relative weight of Characidae fish in Jebel Aulia Dam, Sudan. Int. J. Mar. Atmos. Earth Sci., p. 1-7. 
Ali, M. S., Rahman, M. M., Hossain, L. and Mollah, M. F. A. 2003. Studies on the food habits of three species of Mastacembelidae, Bangladesh J. Fish. Res., 7: 43-52.

Ali, S., Barat, A., Kumar, P., Sati, J., Kumar, R. and Haldar, R. S. 2014. Study of the length-weight relationship and condition factor for the golden mahseer, Tor putitora from Himalayan rivers of India. J. Env. Biol, 35: 225-228.

Almukhtar, M. A., Jasim, W. and Mutlak, F. 2016. Reproductive biology of hilsa shad Tenualosa ilisha (Teleostei: Clupeidae) during spawning migration in the Shatt Al Arab River and Southern Al Hammar Marsh, Basra, Iraq. J. Fish. Aquat. Sci., 11: 43-55.

Bhuiyan, A. L. 1964. Fishes of Dacca, Asiatic Society of Pakistan, Dacca, East Pakistan, p. 118-119.

Chandra, S. 1982. Serum cholesterol levels of 22 species of freshwater fishes. Int. J. Acrd. Ichthyol., 3: 13-16.

Cardoso, R. D. L., Silva, M. H. L., Carvalho-Neta, R. N. F., de Castro, A. C. L., Ferreira, C. F. C., Ferreira, H. R. S. and Santos, D. M. S. 2019. Aspects of reproductive biology of curimba Prochilodus lacustris (Pisces, Prochilodontidae) in a tropical lake in North-eastern Brazil. J. Appl. Ichthyol., 00: 1-13. https://doi.org/10.1111/jai.13868.

Das, M., Dewan, S. and Debnath, S. C. 1989. Studies on fecundity of Heteropneustes fossilis (Bloch) in a mini pond of Bangladesh Agricultural University, Mymensingh. Bang. J. Agric. Sci.,16: 1-6.

Das, S. K. and Kalita, N. 2003. Captive breeding of peacock eel, Macrognathus aculeatus. Aquac. Asia, 8: 17-21.

Day, F. 1878. The fishes of India Today and Tomorrow's Printers and Publishers, New Delhi, India, p. 338-339.

De Carvalho, P. A., Paschoalini, A. L., Santos, G. B., Rizzo, E. and Bazzoli, N. 2009. Reproductive biology of Astyanax fasciatus (Pisces: Characiformes) in a reservoir in southeastern Brazil. J. Appl. Ichthyol., 25: 306-313.

Fontoura, N. F., Braun, A. S. and Milani, P. C. C. 2009. Estimating size at first maturity $\left(\mathrm{L}_{50}\right)$ from gonadosomatic index (GSI) data. Neotrop. Ichthyol., 7: 217-222. https:// doi.org/10.1590/S1679-62252009000200013.

Froese, R. 2006. Cube law, condition factor and weight-length relationships: History, meta-analysis and recommendations. J. Appl. Ichthyol., 22: 241-253. https://doi. org/10.1111/ j.1439-0426.2006.00805.x.

Fulton, T. 1902. Rate of growth of seas fishes. Sci. Invest. Fish. Div. Scot. Rept., 20: 1035-1039.

Hliwa, P., Krol, J., Sikorska, J., Wolnicki, J., Dietrich, G. J., Kaminski, R. and Ciereszko, A. 2017. Gonadogenesis and annual reproductive cycles of an endangered cyprinid fish, the lake minnow Eupallasella percnurus (Pallas, 1814). Ani. Repro. Sci., 176: 40-50. https://doi.org/10.1016/j. anireprosci.2016.11.006.
Hora, S. L. 1935. Physiology, bionomics and evolution of the air-breathing fishes of India. Trans. Nat. Inst. Sci. India, 1: $1-16$.

Hossain, M. A., Afsana, K. and Azad Shah, A. K. M. 1999. Nutritional value of some small indigenous fish species (SIS) of Bangladesh. Bang. J. Fish. Res., 3: 77-85.

Hossain, M. Y., Ahmed, Z. F., Leunda, P. M., Islam, A. K. M. R., Jasmine, S., Oscoz, J., Miranda, R. and Ohtomi, J. 2006. Length-weight and length-length relationships of some small indigenous fish species from the Mathabhanga River, south-western Bangladesh. J. Appl. Ich., 22: 301-303. https://doi.org/10.1111/j.1439-0426.2006.00801.x.

IUCN 2018. International Union for Conservation of Nature and Natural Resources. www.iucnredlist.org (Accessed 10 January 2018).

Jayaram, K. C. 1981. The freshwater fishes of India, Pakistan, Bangladesh, Burma and Sri Lanka. A handbook, Zoological Survey of India, Calcutta, India, 386 pp.

Jakobsen, T., Fogarty, M. J., Megrey, B. A. and Moksness, E. 2009. Fish reproductive biology: Implications for assessment and management. Wiley-Blackwell Scientific Publications, Chichester, UK, https://doi.org/10.1002/ 9781444312133.

Kashyap, A., Awasthi, M. and Serajuddin, M. 2016. Reproductive biology of the freshwater murrel Channa punctatus (Bloch, 1793) from River Gomti of Lucknow region, Uttar Pradesh, India. Indian J. Fish., 63: 126-130. DOI: 10.21077/ijf. 2016.63.3.48294-19.

Khan, M. S. A., Alam, M. J., Rheman, S., Mondol, S. and Rahman, M. M. 2002. Study on the fecundity and GSI of brakishwater catfish Plotosus canius (Ham.-Bucch.). J. Biol. Sci., 2: 232-234. DOI: 10.3923/jbs.2002. 232.234 .

King, M. 2013. Fisheries biology, assessment and management. Blackwell Science, London, UK.

Komsari, M. S., Bani, A. and Khara, H. 2015. Growth and population structure of the European perch, Perca fluviatatilis Linnaeus, 1758 (Osteichthyes:Percidae) in the Anzali wetland south-west Caspian Sea. Indian J. Fish., 62: 6-11.

Lazarus, R. J. and Reddy, P. S. R. 1986. Study on the lengthweight relationship of the littleknown lesser spiny eel, Macrognathus aculeatus (Bloch). Proc. Indian-Acad. Sci, Anim. Sci. 4: 423-427.

Le Cren, E. D. 1951. The length-weight relationship and seasonal cycle in gonad weight and condition factor in the perch (Perca fluviatilis). J. Anim. Ecol,. 20: 201-219. http:// dx.doi.org/10.2307/1540.

Maurua, H., Kraus, G., Saborido Rey, F., Witthames, A. R., Thorsen, P. and Junquera, V. 2003. Procedures to estimate fecundity of marine fish species in relation to their reproductive strategy. J. Northw. Atl. Fish. Sci., 33: 33-54. 
Munro, I. S. R. 1955. The marine and freshwater fishes of Ceylon Department of External Affairs, Canberra, Australia, 267 pp. https://trove.nla.gov.au/version/41071505

Nabi, M. R. and Hossain, M. A. 1996. Reproductive biology of the freshwater spiny eel, Macrognathus aculeatus (Bloch). Bangl. J. Zool., 24: 115-120.

Narejo, N. T., Rahmatullah, S. M. and Mannur, R. M. 2003. Length-weight relationship and relative condition factor (Kn) of freshwater spiny eel, Mastacembelus armatus (Lacepede) from Mymensingh, Bangladesh. Indian J. Fish., 50: 81-87

Parrish, R. H. and Mallicoate, D. L. 1995. Variation in the condition factors of California pelagic fishes and associated environmental factors. Fish Oceanogr., 4: 171-190. https:// doi.org/10.1111/j.1365-2419.1995.tb00070.x.

Prasad, S., Pandey, B. N. and Sinha, D. P. 1983. Seasonal variation in fat and water contents of the Indian freshwater mud eel, M. aculeatum. J. Ani. Phy. Ani. Nutr., 49: 117-126.

Prasad, S., Sinha, D. P., Chanchal, A. X. and Pandey, N. 1979. Ancient.Cienc.-Mar.-Y-Limnol. Univ. Nac.-Auton.-Mex., 6: 59-66.

Qasim, S. Z. and Qayyum, A. 1961. Spawning frequencies and breeding seasons of some freshwater fishes with special reference to those occurring in the plains of Northern India. Indian. J. Fish., 8: 24-43.

Qayyum, A. and Qasim, S. Z. 1964. Studies on the biology of some freshwater fishes. Part. I: Ophiocephalus punctatus Bloch. Bombay Natur. Hist. Soc. J., 61: 74-98.

Rahman, M. M., Ahmed, G. U. and Rahmatullah, S. M. 2006. Fecundity of wild freshwater spiny eel Mastacembelus armatus (Lacepede) from Mymensingh Region of Bangladesh. Asian Fish. Sci., 19: 51- 59.

Rahman, M. M., Miah, M. I., Taher, M. A. and Hasan, M. M. 2009. Embryonic and larval development of guchibaim, Mastacembelus pancalus (Hamilton). J. Bang. Agri. Univ., 7: 193-204.

Rahman, M. M., Hossain, M. Y., Hossain, M. A., Ahamed, F. and Ohtomi, J. 2012. Sex ratio, length-frequency distributions and morphometric relationships of length-length and length weight for spiny eel, Macrognathus aculeatus in the Ganges River, NW Bangladesh. World J. Zool., 7: 338-346.
Rheman, S., Islam, M. I., Shah, M. M. R., Mondol, S. and Alam, M. J. 2002. Observation on the fecundity and gonadosomatic index (GSI) of Liza parsia (Ham.). J. Biol. Sci., 2: 690-693. DOI: 10.3923/jbs.2002.690.693.

Riede, K. 2004. Global register of migratory speciesfrom global to regional scales. Final Report of the R\&D-Project 808 05 081. Federal Agency for Nature Conservation, Bonn, Germany, $329 \mathrm{pp}$

Sahoo, S. K., Giri, S. S., Chandra, S. and Sahu, A. K. 2009 Larval rearing of the spiny eel, Macrognathus aculeatus (Lacepede) under different rearing conditions: a preliminary study. Ind. J. Fish., 56: 47-49.

Sley, A. Hadj Taeib, A., Jarboui, O., Ghorbel, M. and Bouain, A. 2015. Annual reproductive cycle, spawning periodicity and sexual maturity of false scad Caranx rhonchus (Geoffroy Saint-Hilaire, 1817) (Pisces, Carangidae) from the southeastern Mediterranean (Gulf of Gabes, Tunisia). J. Appl. Ichthyol., 1-5.

Sultana, S., Nahar, K., Bir, J., Kabiraj, M. and Khan, M. N. 2017. A quick view on biology of near threatened peacock eel (Macrognathus aculeatus) in Khulna region of Bangladesh. Am. J. Zool. Res., 5: 38-46.

Taki, Y. 1978. An analytical study of the Mekong basin as a biological production system in nature. Research Institute of Evolutionary Biology. Special Publication No. 1: 77, Tokyo, Japan.

Taslim, R., Rashid, H., Sukhan, Z. P., Janat, M. S. and Das, M 2002. A study on the fecundity of a freshwater eel, Macrognathus aculeatus (Bloch) of Mymensingh basin. Bangl. J. Fish., 25: 181-191.

Uthayakumar, V., Sreedevi, P. R., Senthilkumar, D., Munirasu, S., Kiruba, A. and Ramasubramanian, V. 2013. Impact of seasonal variation and feeding on reproductive behaviour of freshwater spiny eel Mastacembelus armatus from Cauvery River. Asia. Pac. J. Rep., 2: 189-195.

Vidthayanon, C. 2002. Peat swamp fishes of Thailand. Office of Environmental Policy and Planning, Bangkok, Thailand, $136 \mathrm{pp}$.

Zargar, U. R., Yousuf, A. R., Mustaq, B. and Jain, D. 2012. Length-weight relationship of the crucian carp, Carassius carassius in relation to water quality, sex and season in some lentic water bodies of Kashmir Himalayas, Turk. J. Fish. Aquat. Sci., 12: 683-689. DOI: 10.4194/13032712-v12_3_17. 